\title{
"IF ON A WINTER'S NIGHT A REVELLER": THE CLASSICAL INTERTEXT IN DONNA TARTT'S
}

\section{THE SECRET HISTORY}

\section{(Part 2)1}

\author{
François Pauw, Dept. of Greek, University of Stellenbosch
}

\subsection{CLASSICAL AUTHORS AND TOPOI}

Classical elements in Tartt's novel can frequently be identified via pointers such as: discussions of classical authors or their works, comparisons between classical figures and characters in the novel, or references to classical topoi in general. When an author is implicitly alluded to without being identified, a grey area is entered where the reader has to decide whether the context warrants a link between a vague allusion and an unidentified author (cf. n.6).

\subsubsection{Similes and metaphors}

Tartt appears fond of employing comparisons, mainly in the form of metaphors or similes, between classical figures, usages or edifices, and characters in her novel. In such instances classical allusions are but stylistic devices in the service of the author or narrator, and not indicative of classical topoi per se. This is commensurate with her penchant for comparing her characters to authors of or characters in post-classical literature. 2 In both instances two purposes are served: to illuminate the character who is compared to the literary original; and, incidentally, to parade the literary erudition of the speaker or narrator (and thus, implicitly, of the authorial persona). In neither case is the original (whether post-classical or classical) of any further relevance to the novel.

On a number of occasions architecture or art is employed as the object of comparison in a simile or metaphor. Thus Julian's profile invites comparison with "an Etruscan in a basrelief" (p.45), while the hole in the roof of Richard's attic room appears to Henry "not unlike the Pantheon" (p.145). Pompeii is twice mentioned in comparisons: the old summerhouse on Francis' country property is described as "a mock tholos, Doric by way of Pompeii ..." (p.92); the effect of the Corcorans' terrace, Richard recounts, is "... postnuclear but ancient, too, like some pumice-strewn courtyard from Pompeii" (p.468). The most elaborate metaphor in the novel is one applied, with poetic mischief, to the physiognomy of Dr Roland, the geriatric psychology professor: "... the creaky machinery of his face began to grind and a cardboard dawn of recognition was lowered, with jerks, from the dusty proscenium" (p.48).

1 This is a continuation of an article appearing in the previous issue of Akroterion [39, (1994):141-163] and should be read in conjunction with Part 1.

2 See Addendum 1 in Part 1 of this article (Pauw 1994:161). 
In some cases mythology provides the basis for a comparison: Thus, Camilla's appearance reminds Richard of a line in the Iliad "about Pallas Athene and the terrible eyes shining" 3 (p.43), while to Bunny, she resembles "a statue of Diana" (p.64). Later, Richard, not without prejudice, compares Henry and Camilla to the sinister duo Pluto and Persephone (p.582). When the police call in a psychic to assist them in the search for Bunny's body, Richard poetically surmises that Henry may be concerned about "some trembling Kassandra gibbering prophecies to a chorus of policemen" (p.425). Slightly later, after the thaw, the feel of the wet grass underfoot conjures up images in his mind of Olympus or Valhalla (p.433).

Not infrequently, the comparison is with personages, whether literary or political, from classical antiquity. Especially Julian becomes the subject of comparisons that are meant to flatter. Thus he is twice compared to Pliny - with respect to his common touch 4 , and his misgivings about Christianity5. Julian's dinners, Richard recounts, had "a sort of Augustan wholesomeness and luxuriance" (p.283), while his brand of ataraxia is described is a "cheery, Socratic indifference to matters of life and death" (p.508). Indeed, when he cautions his students against becoming "too Spartan" in their response to Bunny's death, he uses arguments comparable to those employed, inter alia, in the Phaedo (p.566). Finally, after Julian's reputed but in fact fictitious departure for "Suaoriland", Richard fancifully pictures him as a potential "power behind the Suaori throne", thus comparing him to Platonic theory and Aristotelian practice.7

Julian's students, too, are occasionally compared with classical authors or literary figures. Richard recounts, for instance, how Francis waded into the lake on his property and "beckoned dramatically like Saint John the Baptist" (p.111), while Henry, as counterfoil, is described as "Satan listening patiently to the rantings of some desert prophet" (p.112). Charles, again, epitomizes Henry's aloof and pedantic manner by complaining that he is concerned about mere superficialities, "like if he was carrying the right book, if Homer would make a better impression than Thomas Aquinas" (p.533).

\subsubsection{Authors and genres; isolated topoi}

As may be expected, frequent reference is made, both inside and outside Julian's Lyceum, to classical authors and their works, or to classical topoi in general. Sometimes these allusions form part of a structured discussion of some duration, pertinent to the plot of The Secret History; frequently, however, they are merely made in passing, touching upon no more than historical curiosities of little or no consequence to the plot of the novel, though

3 The unacknowledged source is probably lliad 1.200 .

4 "Julian was greatly admired by the country people who lived around him, much as one likes to imagine that kindly Pliny was held in affection by the poor folk of Comum and Tifernum" (p.247).

5 "Like Pliny ..., he secretly thought it to be a degenerate cult carried to extravagant lengths" (pp.285-286). Cf. Pliny, Letters to Trajan 96.

6 "Who is to say he is not better off now than you are? Or - if death is a journey to another place - that you will not see him again?" In trying to be solicitous, Julian is here mistaking his students' guilt for grief.

7 "What better fate for Julian than ... transforming his pupil into a philosopher-king? ... I like to think that maybe he - as Aristotle did - would bring up a man who would conquer the world" (pp.657-658). 
of interest to students of the Classics. In this section the latter category will be examined; the former will be dealt with in 6.5.3.

Despite the fairly wide range of classical topoi mentioned or discussed in Tartt's novel, the classical authors and works cited by characters are not at all fully representative of GraecoRoman genres. The two genres referred to most frequently, explicitly or implicitly, are philosophy (especially Plato and Aristotle) 8 and epic (especially Homer and Vergil)9.

Plato is mentioned or implied in a variety of contexts. Julian once refers to him as some kind of proto-behaviourist10, and - in support of his own somewhat autocratic teaching methods - as someone who had only one teacher (p.34). Later, he quotes Plato's definition of Justice in the Republic.11 A number of allusions to Plato have a bearing on death or immortality.12 Most of them, however, deal with the theme of "loss of self" and "Dionysiac madness". Thus Julian, in his seminal discussion of that topic, refers to Plato's "four divine madnesses"13 (p.40) and to the danger of losing oneself to lovel4 (p.41). When Henry later tells Richard about their Dionysiac experiment (p.191), he links it to Julian's lecture on Plato's "telestic madness" and stresses the necessity of observing "euphemia, cultic purity" - the cleansing ritual regarded by Plato as a prerequisite for those celebrants willing to "receive the god"15 (p.193).

Apart from unwittingly bequeathing the name of his research centre to Julian's classroom (p.15), Aristotle is mentioned or implied primarily in connection with his drama theory. Thus, Richard commences his narration by mentioning "the fatal flaw" in human character (p.5), which can only refer to Aristotelian hamartia16; when he later recounts his response to Bunny's death, transparently attempting to rationalize his complicity in the murder, he again resorts to phraseology that echoes Aristotle: "While I have never considered myself a very good person, neither can I bring myself to believe that I am a spectacularly bad

8 Other Greek philosophers mentioned in passing include Pythagoras (pp.9-10) and Plotinus (p.39).

9 Hesiod is also mentioned, in a discussion about the question whether his "primordial Chaos" refers to empty space or to the modern concept "chaos" (p.78). The reference is to Theogony 116.

10 "Even Plato knew that class and conditioning ... have an inalterable effect on the individual. ... Psychology is only another word for what the ancients called fate" (p.31).

11 "Justice ... is when each level of a hierarchy works within its place and is content with it" (p.247). This definition occurs in Rep. 4, 433a-434b.

12 E.g. Julian suggests that a passage from the Phaedo would have been more suited to be read at Bunny's funeral (p.499); Richard would have preferred something from Milton's Lycidas (p.488). For a further reference to (Platonic) immortality, see n.6.

13 I.e. prophetic madness, telestic or ritual madness, poetic madness and erotic madness, as defined by Socrates in his "second speech" in Phaedrus (244a-245c; also cf. 265a-b).

14 "As old Cephalus once heard Sophocles say, ... love is a cruel and terrible master." The source of this anecdote is Rep. 1, 329c.

15 Plato uses the term euphemia, approximately in this sense, in Laws 736a and 800c; Phaedrus $257 \mathrm{a}-\mathrm{b}$. Other isolated references to Plato or his dialogues occur on pp.34, 38, 70, and 79 of Tartt's novel. 
one"17 (p.323). It comes as no surprise, therefore, when the term hubris, representing a common exemplum of hamartia in drama theory, crops up later in the same paragraph. Once, indeed, Aristotle is acknowledged explicitly: in discussing readers' response to the depiction of violence and bloodshed in classical texts, Henry refers to Aristotle's view in the Poetics "that objects such as corpses, painful to view in themselves, can become delightful to contemplate in a work of art"18 (p.43).

Of the epopoioi, Homer is mentioned or implied in connection with "the wrath of Achilles" (p.43) and the possibility that Homeric ghosts are the equivalent of "the unconscious" (p.653). Vergil is acknowledged as the author of the Eclogues (p.39); mention is also made of "Dido on the funeral pyre"19 (p.43) and the fate of the missing-overboard-presumeddrowned helmsman Palinurus20 (p.423), the latter reference serving as a parallel to Bunny's unburied state at this stage.

Of the historiographers, only Xenophon (p.41), Thucydides and Suetonius are mentioned explicitly or implicitly. In his initial lecture Julian refers to the passage in which the Delphic oracle promises that Apollo and Athena Nike would aid the Spartans, "invited or uninvited" 21 (p.41); slightly later he gives examples of descriptions of bloodshed, inter alia Suetonius' portrayal of the slain Caesar being carried away on a litter22 (p.43).

In like vein, there are surprisingly few allusions to writers of tragedy (although these are important inasmuch as they all provide a springboard for the Bacchic sub-plot). Aeschylus' Eumenides is implied (p.40) and his Agamemnon mentioned (p.42) by Julian as examples of how passages of madness or gore could convey sentiments of glory or even of beauty; Camilla then illustrates this by reciting the speech Klytemnestra delivers over the body of her murdered husband (Agamemnon 1388-1392). When Camilla later describes their purification ritual to Richard (p.423), Aeschylus' Choephoroi (v.400) serves as the implicit classical intertext.23 No references to Sophocles' tragedies occur in the novel (as may be expected in a text devoid of Sophoclean tragic heroism), but Euripides' Bacchae, which is mentioned or implied when Julian discusses Dionysiac ecstasy and the process of transcending reality with his students, forms such a cardinal subtext that it will be treated separately in 6.5.3.

As is perhaps to be expected in a deadly serious novel, there are no references to writers of comedy or satire. The New Testament merits five allusions 24 ; lyric poetry only two (pp.38,

17 This formulation is strongly reminiscent of Aristotle's view of "the ideal tragic hero" (Ars Poetica 1453a 7-9).

18 The source is Ars Poetica 1448b 10-12.

19 Cf. Aeneid 4. 642-665.

20 Cf. Aeneid 5.833 ff., $6.337 \mathrm{ff}$.

21 The unacknowledged source is Thucydides I. 118.3, where, however, Athena is not mentioned.

22 This description occurs in Suetonius' Life of Julius Caesar, par. 82.

23 See n.84.

24 E.g. Richard admits to having read little more than Koine (p.38); the Bethlehem story from Luke 2 (vv.1-20) is read at a Christmas party (p.136); Paul's sermon on love in First Corinthians (chapter 13) forms the basis of the minister's paramuthia at Bunny's funeral (p.487), while a passage on resurrection (John 11:25-26) is read at the grave (p.496). Later, Dick Spence hands out "a page from the New Testament" in his first class at Hampden (p.615). 
159). Neither Demosthenes nor Cicero is mentioned; likewise, the names and thoughts of Lucretius and Seneca are absent - a curious omission in a novel preoccupied with death.

Of Greek politico-military figures, only Pericles (p.64) and Alexander (pp.34, 658) are referred to - the latter in both cases as a pupil of Aristotle. In addition to Julius Caesar, the names of the first five Roman emperors crop up in discussions, mainly in a negative context.25 Agrippina's name is linked to that of Claudius - not surprisingly, in connection with his, as Seneca would have it, apocolocyntotic and flatulent exit from life (p.284). This passage is preceded by a thematically comparable one where Roman mushrooms, with their Latin names, are discussed with authority by Henry, his purpose being not gastronomic but homicidal (pp.271-273). Other Roman idiosyncrasies discussed include the persecution of Christians (p.46); an obsession with order and, paradoxically, with superstition (p.46); and the formation of Roman legions (p.78).

Greek sexual mores are touched upon in passing, as a parallel to the sexual proclivities of Francis (p.256)26, and of Charles and Camilla27 (p.266). The inferior status of classical

25 Julius Caesar (n. 22); Augustus, Tiberius, Caligula, Nero (pp.45-46, the main point being Tiberius' miserable senility on Capri as a warning against the cultivated repression of impulses); Claudius (p.284). Augustus is mentioned again as the object of Bunny's heroworship: Richard receives a postcard from Bunny, containing a cartoon of Henry and Bunny standing next to a statue of Augustus in Rome (pp.136, 151).

Richard's remark about homoeroticism in classical antiquity ("I don't suppose that anyone who has devoted much energy to the study of Classics can be very much disturbed by homosexuality", p.256) is vague enough to be valid as a generalization. Recent scholarship on the subject cautions, however, against such generalizations, mainly because of the perceived differences between ancient and modern views on homosexual practices. The following perceptions deserve consideration:

1. The view of Halperin, that "the very notions of 'sexuality', 'homosexuality' and 'heterosexuality' are the products of discursive, scientific, and institutional practices peculiar to nineteenth-century Europe" (and thus alien to the ancient world) (Cohen 1992:151).

2. Ancient paederasty was fundamentally different from modern homosexuality, especially in that it was implicitly based on a schema of "male" domination, activity and aggressiveness (as practised by the "senior partner"), versus "female" submission, passivity and inferiority (as experienced by the youthful object of desire). Even a cursory reading of Plato's Symposium would confirm this perspective: the ' $\epsilon \rho \alpha \sigma \eta^{\prime} \zeta$ ('lover') is always depicted as the hunter, and the ¿ $\rho \omega ́ \mu \epsilon \nu 0 \varsigma$ ('beloved') as the hunted. Although homosexual desire for a man was, on the whole, regarded as natural, and thus tolerated, this toleration did not extend to "passive" homosexuals (Gardner 1989:60).

3. Classical Greek views on homosexuality were not uniform: a diversity of attitudes could be discerned among Greek poleis (Pausanias in Plato's Simposium 182ff.; Xenophon, Constitution of the Lacedaemonians 2.12-14).

4. Even in Athens itself, homoerotic practices were not condoned by all. Plato's spokesman in the Laws (835b-842a) shows a preference for a social order conforming to "nature" as it supposedly was before Laios invented paederasty; Isocrates and Aristotle also propose a strict regulation of sexuality in an ideal state.

For a review of recent literature on the subject, see Cohen 1992 and Lambert \& Szesnat 1994.

27 Bunny's sneering reference to Greek incest (p.266) is a product of his gossip-mongering temperament rather than acquaintance with the Stand der Forschung on this rather elusive topic. Consider the following: 
Greek women is also mentioned as a backdrop to Bunny's misogyny28 (pp.263-264).

Judged by the opportunity the Svengali-like Julian has of imprinting his "pagan" views on his students, classical Greek religion receives surprisingly scant attention. Athena is mentioned once (p.434), as a descendant of "owl-headed death gods" at Hissarlik. Dionysus, of course, warrants emphatic mention as the central cultic deity in the Dionysiac rites performed by the four students (see 6.5 .3 below). Further, the reader is reminded, with Judy Poovey, that the Greeks had no Devil (pp.84-85).

A number of references to classical architecture occur in The Secret History, mainly in Henry's account of how Bunny and he experienced Italy. Richard first receives Bunny's cartoon postcard, containing a photograph of the Primaporta statue of Augustus (p.136); later, Henry tells him about their viewing of Etruscan terracottas, the Colosseum, the view from the Palatine Hill, and the bygone beauty of the Baths of Caracalla (p.146). The Colosseum and the Pantheon, as well as the Parthenon, again appear in Richard's surrealist dream at the end of the novel (p.659), where they seem to represent Henry's somewhat phantasmagoric eternal abode.

Greek archaeology, too, is mentioned in passing when Henry, in one of his "didactic monologues", gives an informal lecture on "Schliemann's Ilios" and "the excavation of Hissarlik" (p.434). Later, after a bibliophile shopping spree, Francis brings Henry a corpus of Linear B inscriptions from Knossos as a present (p.504). And finally, when the Dean of Studies pays a surprise visit to Julian's Lyceum, he admits that he expected "something a little more classical. Oil lamps. Discus throwing. Nude youths wrestling on the floor" (p.608).

These examples serve to confirm that frequent reference is made in The Secret History to classical authors and topoi. In a novel with a different cast, such allusions would have appeared contrived; in a novel with students of the Classics as protagonists, however, the classical intertext appears justified. This consideration does not preclude the possibility of the authorial persona using the opportunity to parade her learning via her characters, although, if so, it is less conspicuous than is the case with post-classical allusions. 29

1. At the very least, incest was legally curtailed in classical Athens, owing to a prohibition against the marriage of uterine siblings (i.e. the law permitted half-brother and -sister to marry only if they were descended from different mothers) (Halperin 1990:279).

2. Even granted that incest was not explicitly prohibited in the case of non-uterine siblings, absence of prohibition does not in itself imply social approval (Cohen 1991:174-175). Perhaps the taboo was expressed in an agraphos nomos?

3. The case for an unwritten law is strengthened by the paucity of literary references to incest, and the strong moral disapproval reflected by some of them. A textbook example is provided by Alkibiades being prosecuted by Lysias (14.26-28) for committing incest with his sister (Winkler 1990:190). But then Alkibiades was hardly a paragon of virtue: a prohibition or taboo would have been grist to his mill.

28 "... men have friends, women have relatives, and animals have their own kind" (p.264). For recent scholarship on the status of women in antiquity, see especially Pomeroy 1975, Gould 1980 and Just 1989.

See Addendum 1 in Part 1 of this article (Pauw 1994:161). 


\subsubsection{The Dionysian subtext: Bacchants by imitatio}

The references to classical authors and topoi cited above have been treated separately, so as to demonstrate per genre that they derive from identifiable classical sources. Such an artificial separation may obscure, however, the fact that the allusions in question are frequently sustained during the course of extensive and thematically integrated passages which have a direct bearing on the subject matter and plot of The Secret History. In such cases a more comprehensive discussion is warranted.

The pivotal loci classici, if I may adapt a phrase, pertinent to the plot of Tartt's novel all deal with the conception, preparation, execution and consequences of the Dionysiac experiment conducted by Henry, Francis, Camilla and Charles, and the topos of the Apollinian versus the Dionysiac, which provides the psychological stimulus and ritual framework for this experiment.

To recapitulate: the idea of attempting to recreate the conditions necessary for attaining "Bacchic ecstasy", as experienced by Euripides' Bacchants, is conceived during and inspired by a seminar Dr Julian Morrow conducts on the irrational, the ecstatic, the awesome in Greek thought and literature. This lecture (pp.40-47) constitutes the single section of the novel in which the most numerous, detailed and thematically integrated references to classical Greek literature occur - inter alia to bloodshed in the Oresteia, "madness" in the Phaedrus, ecstasy in The Bacchae, and suppressed emotion in the case of Tiberius. At this stage, Richard regards The Bacchae as a play "whose violence and savagery made me uneasy, as did the sadism of its bloodthirsty god. Compared to the other tragedies, which were dominated by recognizable principles of justice no matter how harsh, it was a triumph of barbarism over reason: dark, chaotic, inexplicable" (p.44). Julian, however, stresses the potentially liberating aspect of maenadism: "To sing, to scream, to dance barefoot in the woods in the dead of night, with no more awareness of mortality than an animal" (p.47). He concludes his lecture by describing "the terrible seduction of Dionysiac ritual" as "that fire of pure being"(p.47).

The above passage seems to presage a more concise passage later in the novel that complements its tone and atmosphere: when explaining the value of Greek prose composition, Richard ponders on the nuances of the word $\pi \hat{v} \rho$ (pp.234-236), as representing the quintessence of the Greek language (and thus of Greek thought). The gist of this gem of a passage merits quotation:

"An incendium is in its nature entirely different from the feu with which the Frenchman lights his cigarette, and both are very different from the stark, inhuman pur that the Greeks knew, the pur that roared from the towers of Ilion or leapt and screamed on that desolate, windy beach, from the funeral pyre of Patroklos.

Pur: that one word contains for me the secret, the bright, terrible clarity of ancient Greek. How can I make you see it, this strange harsh light which pervades Homer's landscapes and illumines the dialogues of Plato, an alien light, inarticulable in our common tongue?" (p.234).

The reputed alterity 30 of Greek culture, however, its seeming inaccessibility, does not

30 For the term (= "otherness"), see Cartledge 1993:2-3. 
discourage the four ${ }^{31}$ students from investigating its more mysterious aspects. In fact, it only fires their romantic imaginations. Their subsequent attempts at attaining "telestic madness" are only hinted at until Henry, apparently forced by circumstances, decides to share their secret with Richard (pp.185ff.). Thus Richard has his misgivings about his friends' furtive and suspicious behaviour confirmed, and Henry has the opportunity of giving Richard, and the reader, a detailed account of the events that led to the death of the Vermont farmer: their infuriatingly hit-and-miss experimentation with different combinations of stimulants, biochemical and psychological, their experiences while under the influence of Dionysus, and the unforeseen consequences of their experiment (pp.191218). Later, Camilla gives Richard her account of what happened in the course of their Bacchic intoxication (pp.422-424). Finally, Henry, when pressed by Richard, tells him how his "stale and colorless" life has metamorphosed into one vibrant with a "surge of power and delight, of confidence, of control" (pp.583-584). The catalyst in the transformation of Henry's existence was primarily the killing of the Vermont farmer (p.583), although he acknowledges their decision to kill Bunny as a factor that further triggered his self-liberation (p.584).

These four passages (pp.40-47, 191-218, 422-424, 583-584) form the gist of the jig-saw puzzle that the reader has to assemble in order to form a comprehensive picture of the role the Dionysiac plays in The Secret History. In the discussion that follows, the preparations for, execution of and consequences of the four students' Dionysiac ritual will be described, with reference to the relevant passages. Where applicable, comparisons with Euripides' depiction of Dionysiac ecstasy in The Bacchae will be drawn. In conclusion, the credibility and effectiveness of Tartt's adaptation of the Euripidean topos will be evaluated.

\section{Euripides' Bacchae}

The plot of The Bacchae of Euripides, first staged posthumously in 405 B.C. in Athens, could be summarized as follows: Pentheus, the puritanical king of Thebes, feels threatened by the worship of Dionysus, god of religious ecstasy, exuberance and vitality, and a late addition to the Pantheon. Despite due warning by Dionysus (in the persona of a Dionysian priest), Pentheus rejects the new-fangled religion on behalf of his citizens. In retaliation, Dionysus maddens the women of Thebes who, as Dionysiac maenads, tear apart a deluded Pentheus in a sacrificial rite of divine vengeance. To add insult to injury, as it were, this sparagmos ritual culminates in Pentheus' mother Agave, witless, holding what proves to be her son's severed head. In the exodos, an epiphanic Dionysus prophesies Agave's exile, the metamorphosis of her father Kadmos into a serpent, and the depopulation of Thebes. This is the terrible price exacted when a god is slighted.

\section{Preparation}

When Henry matter-of-factly admits to Richard: "We decided to try to have a bacchanal" (p.191), the latter is incredulous. Bacchanals, after all, are for choruses in late-Euripidean drama, or at most they are outdated pagan rituals as described by Pausanias or Plutarch ${ }^{32}$,

31 When Bunny proved impervious to the dietary discipline and underlying seriousness of the original quintet's enterprise, he was excluded from the group, leaving Henry, Francis and the twins as active participants (p.195) and Julian as the silently acquiescing patron (p.283). See Pauw 1994:144.

32 Dodds 1960:xiii-xiv mentions Pausanias 10.32.5 and Plutarch De Primo Frigido 18, 953D as sources for institutionalised maenadism in Hellenistic times. 
hardly to be taken seriously in the late twentieth century. In Henry's fairly detailed description that follows, however, it becomes clear that he is deadly serious. He acknowledges Julian's lecture on the Dionysiac as the source of their inspiration, as the catalyst that triggered their experiment. Their purpose was "to escape the cognitive mode of existence", ... "to lose one's self" (p.192). In the event, ancient sources did not prove very helpful in furnishing detailed descriptions, psychological or pharmaceutical, of the procedures to be followed in order to become a Bacchant. They experimented with "drink, drugs, prayer, even small doses of poison" (p.192), as well as vigils, fasting and libations (p.193); they even burned hemlock branches and breathed the fumes, and tried to chew boiled laurel leaves 33 (p.193). Moreover, they made chitons (cf. p.107) from bed sheets 34 in Francis' attic, and gallivanted "drunk and in chitons and singing Greek hymns like something from a fraternity initiation" (p.193). But as Euripides or Dodds could have told them, intoxication or fancy dress alone would not be likely to do the trick. 35 Experimentation with mind-changing substances might have sufficed as poetical inspiration for Coleridge and De Quincey, for Eugène Marais and Aldous Huxley, for Timothy Leary and Carlos Castaneda, but something less substantial and more intangible was called for if one really wanted to meet Dionysus. "To leave no turn unstoned" would provide a trip, but no oreibasia.

Henry attributes the failure of their initial attempts to erroneous deductions he made from accounts of a different psycho-trip in the ancient world, that of the Pythia at Delphi. Originally he assumed that the Pythia's method of intoxication - "the pneuma enthusiastikon, poisonous vapors and so forth"36 - was related to that employed by Dionysiac maenads (p.193). But he was mistaken - Delphic Apollo and Theban Dionysus should not be confused, despite the latter's winter sojourn at Delphi (Cilliers 1986:3).

In this way, they reached an impasse in their trial-and-error search for "the ultimate trip". As a second tack, Henry recounts, they had recourse to symbolic acts of cleansing in order to attain cultic purity (euphemia). Thus inspired, they tried "water poured over the head, baths, fasting" (p.194). Once again, however, their strategy proved ineffective, until eventually Henry had a brainwave: "... any religious ritual is arbitrary unless one is able to see past it to a deeper meaning" (p.194). To attain such a state, Henry explains, one should

33 Now only can Richard understand the function of the "large copper pot" filled with "limp, almond-shaped leaves" that so baffled him when he discovered it in Francis' country house (p.107). Be that as it may, the chewing of laurel leaves has been shown to have no discernible psychological effects: "Professor Oesterreich once chewed a large quantity of laurel leaves in the interests of science, and was disappointed to find himself no more inspired than usual" (Dodds 1951:73).

34 In The Bacchae, chitons are thought of as exclusively feminine attire: see Dodds 1960:176-177.

35 Although in Dionysiac ritual wine was seen as a way of helping the votary achieve communion with Dionysus, it was of secondary importance. In fact, in The Bacchae the maenads are by no means inebriated, despite Pentheus' assumption that they are (260-262). "Their ecstasies were of an ascetic rather than sybaritic nature" (Young 1993:266). Other references to the innocuous use of wine in The Bacchae confirm the maenads' moderation: cf. 278-285, 312-313, 378-386, $534-535,686-688,707,771-774,814$. For a more detailed discussion of the role of wine in Dionysiac ritual, see Dodds 1960:xiii; Cilliers 1986:10-11.

36 The "vapour theory" has long been discredited to account for mantic inspiration at Delphi: "The limestone clefts of Delphi might occasionally produce outrushes of cold air, but it would have no chemical properties capable of intoxicating ..." (Parke 1967:79). See further Dodds 1951:73-74; Green 1989:91-111 (esp. 101-104, 107-108, 110). 
experience "belief, and absolute surrender". Their venture had to be approached "on its own terms, not in a voyeuristic light or even a scholarly one" (p.194).

To readers skeptical of the hermeneutics of "deeper meaning", this insiglt of Henry's might seem like happy-clappy gobbledygook, devoid of any meaning at all; but in fact it is in accord with the view of commentators on The Bacchae.37 Furthermore, it is an assumption shared by belief systems as diverse as microphysics and Zen Buddhism.38 The Cartesian subject-object dichotomy is today widely regarded as outdated, and logical positivism has been overtaken by holism. But this is nothing new: it harks back at least to Herakleitos, and has been reaffirmed by existentialist philosophers such as Kierkegaard and Heidegger.39 When the normally rational Henry starts spouting the terminology of religious fervour, therefore, it is not New Wave desperation gone haywire; rather, it represents an established tradition of communion with the numinous, bridging cultures and eras.

\section{Execution}

Thus it came about that Henry took recourse to a third strategy, this time with a seriousness of purpose that had to exclude Bunny's frivolity (p.195; cf. n.31). Henry and his three remaining co-devotees fasted for three days; a messenger came to him in a dream. 40 And then it happened: "the ultimate trip" became a reality, at least in the minds and memories of the four participants. In the first place, with the expansion of their psyches visual images abounded: Dionysian symbols reminiscent of The Bacchae, such as bulls, snakes, vines and torches (pp.196, 422). When Camilla later telis Richard of her experiences during their Dionysiac experiment, she remembers "... a pack of dogs.41

37 "B $\alpha \kappa \chi \epsilon \in \in \epsilon l \nu$ is not to have a good time, but to share in a particular religious rite and (or) have a particular religious experience - the experience of communion with a god which transformed a human being into a $\beta \alpha ́ \alpha \chi \chi \varsigma \varsigma$ or a $\beta \alpha ́ \alpha \chi \eta^{\prime \prime}$ (Dodds 1951:278 n.1). Cilliers (1986:12), too, calls such an experience "mistieke eenwording". Also cf. Young 1993:114 ("self-abandonment").

See Capra 1983 and Zukav 1979. In fiction, this synthesis of science/technology and mysticism achieved counterculture status via Robert M. Pirzig's best-selling novel Zen and the art of motorcycle maintenance in the seventies, a text which probably also provides an intertextual basis for Henry's experience. More recently, this topos has been popularized by Berndt Capra's intellectually enthralling film Mindwalk, starring Liv Ullmann as a physicist-turned-holist. Note, however, that Henry regards his experience as superior to that of "Eastern religions" (p.196).

39 To experience ekstasis, one has to exist, in the frequentative sense of exstare: existere - to "continue stepping out" of the limitations imposed by inhibition, or the left brain, or the normal rules of logic, and "become one" with something outside oneself. This intuitive process of self-transcending is not only commensurate with Sören Kierkegaard's philosophy of "authentic existence", but also echoes Julian's initial lecture, where he eulogizes the beauty of losing control completely - "to throw off the chains of being for an instant, to shatter the accident of our mortal selves" (pp.46-47).

40 Dodds 1951:107 categorizes different perceptions of dreams in classical antiquity. Of his categories, the chrematismos or "oracle" is probably applicable to Henry's dream. It is said to occur "when ... the dreamer's parent, or some other respected or impressive personage ..., reveals without symbolism what will or will not happen, or should or should iuv be done." 
Snakes twining around my arms. 42 Trees on fire 43 ..." (p.422). Henry also has memories of Bacchae-like phenomena: "Torches44, dizziness45, singing46. Wolves howling47 around us and a bull bellowing48 in the dark. The river ran white49." (p.196).

Secondly, the intensity of sensory stimuli led to a distorted perception of time, superseding the linear time perception belonging to clockwork reality: "It was like a film in fast motion, the moon waxing and waning, clouds rushing across the sky. Vines grew from the ground so fast they twined up the trees like snakes 50 ; seasons passing in the wink of an eye" (p.196). In the third place, the boundaries of the self disintegrated: "duality ceases to exist; there is no ego, no ' $\mathrm{I}$ ' ..." (p.196). This abolition of the subject-object dichotomy went hand in hand with partial amnesia and the absence of pain. In addition, sexuality did play a role in their experience - "a certain carnal element", as Henry grudgingly concedes51 (p.197). Finally, the presence of Dionysus was sensed by the participants. When Henry attempts to describe how they had "seen" Dionysus, he becomes defensive: "You don't know what Dionysus looks like. We're talking about God here. God is serious business"52 (p.197).

42 Cf. Bacchae 101-102, 697-698, 767-768, 1017-1018, 1330-1331, 1357-1359.

43 Cf. Bacchae 757-758, 1082-1083.

44 Cf. Bacchae 144-147, 306-307.

45 For trances and hallucinations, cf. Bacchae 629-630, 918-921, 1268-1270.

46 Cf. Bacchae 71-72, 1056-1057.

47 Cf. Bacchae 699-700.

48 Cf. Bacchae 99-100, 618, 743-744, 920-922, 1017, 1159, 1185.

49 Cf. Bacchae 1093-1094.

50 In The Bacchae vitality and fecundity are embodied in evergreen ivy, and especially in ivy wreaths, rather than in vines: cf. 106, 177, 253, 1169-1170. But the fruit of the vine obviously plays a significant role: cf. 221-222, 260-262, 278-283, 313, 378-386, 534-535, 686-688, 707, $771-774,814$.

51 Barring the depiction of a few intimate kisses (pp.81, 340, 536), there are no explicit sex scenes in The Secret History; when reference is made to the sexuality of characters, the tone is subdued and the language almost euphemistic, even in the case of Richard's one-night-stand (pp.336-337). Such primness is representative of neither sexual mores nor literary convention in the late twentieth century; it merely serves to substantiate the view that Tartt's characters live in a time-warp (see Pauw 1994:151-152).

In The Bacchae, likewise, the maenads are not depicted as indulging in erotic excesses. Their mania is not the hysteria of the womb, as etymology would have one believe; rather, it is "hysteria subdued to the service of religion" (Dodds 1960:xvi). The maenads are suspected of serving Eros or Aphrodite only in Pentheus' voyeuristic imagination (222-225). For further references to the inhibited nature of the bacchants' sexuality, and to Pentheus' fantasies, cf. 314-318, 457-459, 485-488, 683-688, 773, 957-958.

52 This is not simply an evasive answer, but, I think, an honest attempt to accomplish the impossible, viz. to give a verbal description of a profound religious experience to a nonparticipant. Once objectified, the experience loses its original impact in that it is not experienced any more, but relegated to the realm of "facts". Thus the holistic effect of the original experience is perforce fragmented and adulterated. 
When Camilla later shares her memories of their bacchanal with Richard, she also mentions experiencing the presence of Dionysus: "There was a fifth person with us for part of the time" 53 (p.422). When pressed by Richard, she describes this "presence" as male and female in turn, attributing such a metamorphosis to Dionysus' epithet $\pi 0 \lambda v \in i \delta \eta^{\prime} \zeta$ ("multiform")54.

\section{Anagnorisis}

Continuing his account, Henry tells Richard how they came to their senses after their encounter with Dionysus. Here the implicit author uses the ploy of encumbering the celebrants with partial amnesia5s (pp.197-198), thus ensuring that their accounts would collectively represent an incomplete jig-saw puzzle, hazy and indistinct. In fact, in large part their nocturnal activities can be reconstructed only when they are confronted with their physical state and the material evidence of what they have done. The following picture emerges: although all four celebrants are bruised and scratched, Charles looks worst. He has a bloody bite mark, clearly not of human making, on his arm (pp.197, 211), and his back is riddled with thorns (p.212). Francis is so covered with blood that his chiton sheet sticks to his body when he later wants to undress (p.210). Camilla's hair is "dark and clotted, completely soaked. As if she tried to dye it red" (p.199). She recalls that during part of the bacchanal, she believed she was a deer (p.197). This dovetails with her friends' recollection of chasing a deer through the woods - for seven or eight miles, as they later deduced56 (p.198) - and echoes Julian's lecture-room description of a Euripidean Maenad:

53 Sensing or perceiving the presence of an unidentified person or power is an accepted phenomenon amongst Himalayan mountaineers in the "death zone" (above 8000 meters). Whether this should be attributed to the biochemical effect of oxygen depletion on the brain, to the presence of the mountain god Chomolunga, or to compulsive guiding behaviour amongst the ghosts of deceased mountaineers, I am not in a position to ascertain. I do know, however, that such experiences are so common as to be taken seriously. A fairly recent account is to be found in Venables 1989:169-174.

Likewise, it falls outside the scope of this article to categorize the experience of Henry and his fellow-devotees in terms of any mental state known to modern (para)psychology. It is immaterial whether they are in the grip of hallucinations, auto-suggestion, or a biochemical imbalance induced by fasting. The point is that they simply accept that they have had communion with Dionysus, instead of rationalizing their experience. When even Henry temporarily discards the cautionary filter of reason, it surely points to an unusually profound experience.

54 Cf. Bacchae 478. Dionysus can appear as a god, or in the guise of (effeminate) man, or as animal (bull, snake, lion). In The Bacchae, numerous other epithets further emphasize Dionysus' versatility (Cilliers 1986:5): Bromios ("Roarer"), Euios (god of paians), Iakchos (god of the ritual cry); Anthios ("Blossom-bringer"), Karpios ("Fruit-bringer"), Lysios ("Liberator from sorrows"). Dodds (1960:xii) adds Dendrites or Endendros ("Tree-power") and Phleus ("Abundance of life").

Cf. Agave, who also experiences amnesia when recovering from her trance (Bacchae 1272).

This scene reminds one of Dionysus' dual role as "the hunted and the hunter" (Dodds 1960:xx); it probably also has sexual connotations (cf. pp. 196-197, 421).

When Bunny later notices his friends' suspicious appearance ("all white robes and bloody like something from Edgar Allan Poe"), Henry resorts to using the lame excuse that they hit a deer with their car (p.209). Bunny's response is understandingly cynical (pp.213, 214, 317). For further references to deer, see pp.200, 517. 
"more like deer than human being"57 (p.47).

Henry vaguely remembers that he twice hit out at "a large, indistinct, yellow thing" (p.198). Charles recalls pulling hard at a man's arm, his foot braced in the armpit58 (p.199). Only when the moon came out did Henry acquire the lucidity to notice the body of a man at their feet, his neck broken and his brains "all over his face" (p.198). Henry's hands and spectacles were ominously bloody (pp.198-199). Camilla later (p.422) adds that the dead man's stomach was torn open; a newspaper report would describe the body as "mutilated" (p.366).

When they thus come to recognize the gory consequences of their bacchanal, it constitutes a cognitive and emotional anagnorisis akin to that of Agave in the exodos of The Bacchae. In fact, judged by Henry's account the manslaughter represents a sparagmos ritual (the tearing apart of a victim while under Dionysus' influence) as it is thrice described in The Bacchae. 59 Not surprisingly, Henry's account reminds Richard of what I would call the Senecaesque in The Bacchae: "hooves and bloody ribs, scraps dangling from the fir trees"60 (p.213). But whereas Euripides mentions the eating of the victim's raw flesh (omophagia)61, although with less gore than Seneca would have done, Tartt's characters stop short of that.

\section{Comparison}

Where Tartt has deviated from her Euripidean model, it can in most instances be attributed to a difference in genre convention and Zeitgeist. The following differences are the most conspicuous:

1. Tartt has dispensed with both Euripides' main chorus of Asiatic Bacchants and his parachorema of Theban Maenads. The logistics of adding at least a dozen supernumeraries (chanting dons? rapping students?) to an oreibasia of which the main prerequisite is furtiveness, would have complicated the plot beyond verisimilitude; moreover, the convention of a chorus, indispensable to Greek tragedy, would have seemed either antiquated or spurious in a predominantly realistic novel, unless adapted beyond recognition.

Nevertheless, Euripides' parachorema find its parallel in Tartt's four Bacchants. In both texts the respective Bacchants are responsible for bloodshed while under the influence of Dionysus; moreover, they do so "off-stage", thus necessitating an eyewitness description (by Euripides' Messengers and by Tartt's characters Henry and Camilla, respectively), instead of the author dramatizing the events directly.

57 For references to live deer in The Bacchae, see vv.138-139, 699-700, 866-867.

58 When dismembering Pentheus, Agave uses the same grip (Bacchae 1125-1127).

59 The victims are a goat (135-138), cattle (734-747) and Pentheus (1122-1142), respectively. Note that Tartt follows Euripides' Greek convention in employing a "messenger speech" of sorts to report the sparagmos, instead of directly portraying it.

60 The unacknowledged source is Bacchae 740-742.

Bacchae 138. 
2. In Euripides' play, the opposition of conflicting value systems and moral codes is embedded in the stable matrix of kinship patterns and the cohesion that the polis offers as a politically unifying factor. Consequently, the fates of Pentheus, Kadmos, Agave and the citizens of Thabes are inextricably entwined.

No comparable matrix exists in Tartt's novel. Next to no emphasis is placed on man as a zoon politikon: the only social structure binding together her protagonists (and later enmeshing them) is a friendship of convenience based on the coincidence of their having enrolled for the same course.

3. There is an unambiguous causal link between Pentheus' defiance of, and his punishment by, Dionysus. Such an aetiology cannot be established in the case of the Vermont farmer, whose death is totally fortuitous (see 7.2 below) and whose attitude toward Dionysus, if any, is not known.

4. There are significant differences between the socio-cultic status accorded the Bacchants in the Greek model, and that reflected in its intertextual heir: whereas the maenadism practised in The Bacchae is commensurate with Athenian myth, if not always with late fifth-century cultic practices 62 , the bacchanal depicted by Tartt is highly experimental, not constituting a part of any established twentieth century religion. (In California it could have been, but not in Vermont.) By the same token, most readers will probably accord less credibility to notions of divine intervention in Tartt's novel than in Euripides' play.

As has been demonstrated in passing, Tartt's depiction of the four students' nocturnal bacchanalia owes much to Euripides. In summary, the following points of resemblance may be noted: locality63, season 64 , hour 65 , dress 66 , activities67, psychological state and

62 Albert Henrichs argues persuasively for a distinction "between the Dionysus of myth and the Dionysus of cult, between the Euripidean and Aristophanic Dionysus, or as Plutarch and


(1990:271). His arguments are based on the view that The Bacchae represents "a divinelyinduced perversion of actual cult" (1990:257), portraying "a worst-case scenario characterized by a disturbed relationship between men and gods, and by the temporary suspension of normal civic and social mechanisms, including cults" (1990:258). Such a view is substantiated by reference to, inter alia, the depiction of Dionysus in the fifth stasimon of Sophocles' Antigone (as god of the afterlife), and in Aristophanes' Acharnians (as rustic god of peace). To that I would add the Dionysus of Frogs - bumbling buffoon and cringing coward, but also literary arbiter and linked to Eleusinian afterlife - with the proviso that one should allow for comic satire, to which, of course, not even the gods were immune.

At any rate, it should be clear that the depiction of Dionysus in The Bacchae as vengeful is not representative of Dionysian cult in 405 B.C.

63 Henry wrongly locates the setting of the maenads' oreibasia in the Peloponnesus (p.195); in fact, it is on Mt. Kithairon near Thebes (Bacchae 661, 1045). By transferring the scene to New England, Tartt establishes a comparable atmosphere and topography: hilly country suited to an oreibasia; an apparent locus amoenus that proves to be a treacherously harsh place where the laws of nature are followed relentlessly.

64 Bacchae: midwinter (Dodds 1951:271); The Secret History: "late Fall", later specified as 10 November.

65 In both cases at night (Bacchae 485-486; The Secret History pp.195, 198). 
methods of attaining it68.

\section{Life and death}

There is one further resemblance between Tartt's novel and The Bacchae that warrants fuller treatment. The antithesis between life and death plays a significant role in both works.

In The Bacchae, Dionysus embodies various polarities: sanity vs. madness, reality vs. illusion, divinity vs. bestiality, order vs. chaos.69 The omophagia ritual even gives substance to the Lévi-Straussian construct of "the raw" vs. "the cooked" (i.e. nature vs. civilization). Significantly, Dionysus symbolizes life as well as death. As immortal god he was born of a mortal woman70; in the play he in turn dons the persona of mortal visitor from Lydia (vv.55, 464) and epiphanic divinity (prologue, exodos). Like the Hindu god Kali, he not only engenders creative energies, but also unleashes destructive forces; in him fertility and decay, vitality and moribundity are united. Dionysiac initiands probably had to die, symbolically, in order to be reborn (Seaford 1981:261), but no such rebirth is granted the dismembered Pentheus71, unlike Pelops (Seaford 1981:266). Pentheus is killed because he denies the Dionysiac principle of vitality and spontaneity in himself and his subjects; for the same reason Agave, out of her wits, is made to kill her son unwittingly. The roles are reversed when the would-be hunter is hunted by his hunted-turned-huntress mother.

Such a life-death antithesis also finds expression in Tartt's novel. Hampden College is portrayed as decadently vibrant with student life. This oxymoron applies to the Lyceum as well: apropos of Julian's views on bloodshed in Greek literature, Henry remarks that "death is the mother of beauty" (p.43). The converse of that, as Bunny notes, is the desire

66 The Euripidean maenads are dressed in fawnskin (Bacchae 24, 111, 136-137, 176, 249, 696698 ) - according to Maxwell-Stuart (1971:437-439), to provide them with magical protection against snakes, on account of the perceived ability to deer to kill snakes. The white sheets that

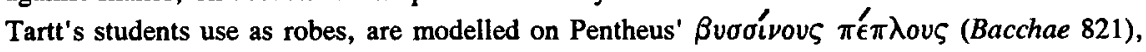
which may have a funerary symbolism (Seaford 1981:260-261).

67 In both tragedy and novel the celebrants are depicted as running without getting tired (Bacchae 746-747, 872, 1090-1091; Tartt p.198), performing superhuman feats of strength, and indulging in a sparagmos. In both works they sing hymns (Bacchae 155; Tartt pp.192-193). Dancing, an activity frequently referred to in Euripides' tragedy, is not mentioned in Henry's account. But cf. Young (1993:266), who pictures the dancing of maenads on the slopes of Parnassus as "more like a wild and abandoned running".

68 The students' attempts at attaining Dionysiac ecstasy are directly based on classical sources (pp.44, 192-193). Comparable methods are presumably used by Euripides' bacchants, but this is conjecture. In both cases the personalities of the celebrants are invaded by Dionysus' power (n.54), followed by partial amnesia (n.55); afterwards, they return to a normal mode of cognition.

69 The paradigm followed is the structuralist approach, by now entrenched in Euripidean criticism by especially Charles Paul Segal. The most relevant of his voluminous contributions appear in the Bibliography.

Bacchae 2-3, 39-42.

71 Suggestions of a rebirth, perhaps borne out by Bacchae 963-970 and Dionysiac ritual (Seaford 1981:267), are rejected by Segal 1982:37-38. 
"to live forever" (p.44), a phrase not only echoing Plato's Symposium72, but also gradually ritualized into a toast (pp.104-105) by the group, and acquiring proleptic irony after Bunny's death. Julian concludes his discussion of the Dionysiac by optimistically endorsing the revitalising aspect of Dionysus: "let God consume us, devour us, unstring our bones. Then spit us out reborn" (p.47). Two homicides later, it transpires that neither the farmer nor Bunny is to be reborn in the novel, although the farmer will haunt them from his grave in newspaper reports (pp.215, 366). The only rebirth that could later be detected, is that represented by the curious feeling of liberation Henry experiences (pp.583-584), but even that is ultimately rendered invalid by his suicide. His friends' psyches are consumed, without any compensatory rebirth, but rather with a grotesque afterbirth of guilt, remorse, angst and self-loathing. Francis attempts to commit suicide with a razorblade, Charles with liquor, Richard with self-pity. Life has become unlivable.

Death is implicit in life, as Tartt conveys with ironic juxtaposition. When Bunny, unaware of his friends' intentions, stumbles across them above the ravine, he cannot refrain from sarcastically asking: "What are you doing, burying the dead?" (p.317). His last words are meant to refer to the death of the Vermont farmer, but the reader might proleptically apply it to Bunny himself. At Bunny's funeral the officiating minister reads from John 11:25-26: "I am the Resurrection and the life; he who believeth in Me, even if he die, shall live ..." (p.496). From the point of view of Bunny's friends, however, he is only reborn in dreams 73 and look-alike relatives 74 . Julian speculates that Bunny may be better off now and that, if death is a journey to another place, his friends may see him again (p.566). In Francis' suicide note he, too, perceives death as emigration, or as sleep (p.647).

Henry's feeling of liberation and vitality after the homicides is somewhat enigmatic. Shortly before his suicide, he explains to Richard that prior to the manslaughter his life used to be "stale", "colorless" and "dead" (p.583), but subsequently he could "live without thinking" (p.584). Before Bunny's death he felt "paralyzed" and "immobilized"; after the ravine episode, he experienced "power" and "control". Yet the net result is that "there's not much that matters a great deal" (p.584). Such nihilism eventually has to culminate in suicide. In fact, it is but an extension of the Gatsbyesque ennui the group wallows in. On occasion, Francis drunkenly quotes Rimbaud: "dormir plutôt que vivre." Henry completes the quotation: "Dans un sommeil aussi doux que le mort ..." (p.231). Instead of gentle dreams, however, he is granted dreamless death - although Richard would still dream of him (pp.658-660).

It thus transpires that both their jovial toast to life and Julian's promise of a Dionysiac rebirth are made a mockery of. Like Pentheus in The Bacchae, they are torn apart. Like Agave, they are racked with guilt, filled with horror, and exiled from normality. But unlike $\operatorname{Kadmos}^{75}$, they receive no prophetic promise of an ultimate Elysian abode. "To live forever" has become a sentence of lingering death, unmitigated by Bunny's cheery optimism. Mors longa, vita brevis ....

72 See especially Symposium parr. 206c-208b.

73 Particulary Richard (pp.346-347, 500-502, 576) and Charles (p.559) are haunted by nightmares about Bunny's death.

74 At Bunny's funeral Richard's guilty imagination recognizes Bunny's features and voice in those of his father (p.456) and his brothers (pp.464, 468): "Bunny's death was starting to seem some horrible kind of generative act, more Bunnys popping up everywhere I looked ...." 


\section{EVALUATION}

A number of interrelated questions remain to be examined with a view to evaluate The Secret History: the nature of the five conspirators' nemesis (how were they punished?); the nature of their hamartia (why were they punished?); and the moral significance of the novel (the didaskalos factor: what can one learn from it?). As the terminology indicates, these three questions are all classical in origin, providing an implicit intertextual framework which gives a diachronic perspective to the evaluation of Tartt's novel.

\subsection{NEMESIS}

Pentheus' nemesis in The Bacchae is simple, if unpleasant: he is torn apart by his mother, Agave. The punishment incurred by the culprits in The Secret History is more complex, partly because it appears to be ordained by the murky rules of the human psyche rather than by the explicit pronouncements of an epiphanic deity, partly because of the dual nature of their crime and culpability.

The manslaughter and subsequent murder encumber the perpetrators with unforeseen consequences on a legal, moral-psychological and ritual level. The legal implications of the farmer's death are clear-cut, if harrowing. Turning themselves in to be tried for manslaughter never represents a serious option for the four modern-day maenads, particularly in view of the certain prejudice of a rural Vermont jury against drunken students trespassing in the dark of night (pp.203-204). Henry's view of their culpability is predictably clinical and cynical: "Frankly I do not see how well either the taxpayers' interests or my own would be served by my spending sixty or seventy years in a Vermont jail" (p.203). Later, Francis expresses his remorse at the farmer's death, but adds revealingly: "I mean, this man was not Voltaire we killed" (p.230). Such a rationalization betrays the relative and opportunistic nature of the students' moral framework, and will cost Bunny his life. Had they been brought to justice after the first murder, there would have been no motive for the second: silencing Bunny would have become redundant.

Bunny's response to his initial suspicions (pp.214-216) and subsequent confirmation (p.223) of the manslaughter is one of overt glee and schadenfreude, as witness his insensitive jail jokes (pp.179-181). Such blabbering seals his fate, which differs from that of the farmer in that it is premeditated. When Henry is coolly calculating Bunny's murder, he is not unaware of the legal consequences: "I'd rather go to jail than know that Bunny was going to be hanging around my neck for the rest of my life" (p.279). Yet his aim is

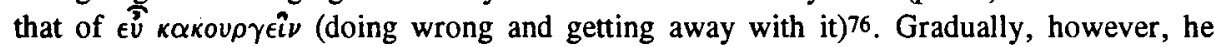
and his friends come to realize that getting away with it is bought at the price of an everpresent, lifelong fear of exposure. Keeping a guilty secret can be a harrowing business. As


of his tether, later realizes that there is no statute of limitations on murder: "there was no guarantee it wouldn't surface again a year, twenty years, fifty years from now" (p.578).

The psychological and moral consequences of the manslaughter, secondly, are relatively straightforward. In general, the perpetrators' states of mind are more influenced by fear of the legal consequences of their Bacchic frenzy than by consistent guilt, remorse or

76 For the term, see Dodds 1951:188; for classical examples, his n. 58 (p.200). De Jong 1994:9 notes the parallel of Dorian Gray, who, like Henry, regards herself as above homicide laws and normal feelings of guilt.

"Time brings all secrets to light" (Philemon, Fragm. 192 Kock). 
contrition. Their response is encapsulated in Henry's factually concise deprendi miserum est 78 (p.202). Not surprisingly, he plays down the manslaughter as "a minor thing, really. An accident" (p.191), thus evading the moral responsibility of letting justice run its course.

The psychological states of the culprits are vastly complicated by the premeditated nature of Bunny's murder. Book II of the novel reads like a bleak enumeration of destructive emotions and forms of behaviour. Although Henry callously refers to Bunny's death as "a redistribution of matter" (p.355), his friends are sensitive enough to experience the whole gamut of terrifying emotions and sensations: horror 79 (pp.326, 494), depression and angst (p.332), regret and remorse80 (pp.370-371, 458, 489, 595, 599), guilt and worry (pp.450451), psychosomatic pain and illness (pp.325, 489, 496), palpable fear of detection (p.578), humiliation81 (p.601).

Such an atmosphere of horror and revulsion is reinforced by the gloomy and the grotesque, the morbid and the macabre, as manifested in quotations from and references to, e.g., Cocteau (p.393), Dante's Purgatorio and Inferno (pp.397, 414, 658) and Sartre82 (p.496). Richard's feeling of guilt and fear is sombrely encapsulated in his compulsive thoughts about Rashkolnikov's eventual confession in Crime and Punishment: "It was I killed the old pawnbroker woman and her sister Lizaveta with an axe and robbed them" 83 (p.468). Most terrifying of all are the nightmares about Bunny that haunt his murderers (see n.73), exposing their feelings of guilt while also serving as psychological punishment. This is exacerbated by their inability to sleep without medication (pp.576, 580).

In the third place, the murders even have consequences on a ritual level. The significance of miasma in the novel is already foreshadowed at the very beginning of Richard's tale, where he is melancholically aware of a miasma pervading his Californian milieu (p.9). After the manslaughter, however, miasma becomes synonymous with guilt. The very first actions of the group coming home from their bacchanal acquire a cultic symbolism: they wash themselves thoroughly and burn their blood-stained chitons (p.212). This is still in part pragmatic, but Camilla later mentions a purely cultic expiation ritual that Henry made them perform "a couple of days after that thing in the woods": letting a slaughtered piglet bleed on them, with the Oresteian assumption that "the only way to purify blood is through blood"84 (p.423). Thus their pollution was to be neutralized by a purification ritual, and

78 "It is a grim prospect to be caught."

79 After Bunny's death, Richard attempts to articulate his emotions: "Some things are too terrible to grasp at once. Other things - naked, sputtering, indelible in their horror - are too terrible to really ever grasp at all. It is only later, in solitude, in memory, that the realization dawns: when the ashes are cold; when the mourners have departed ..." (p.326).

80 "Suddenly ... I was struck by the bitter, irrevocable truth of it; the evil of what we had done" (p.458).

81 "What I felt ... was not fear or remorse but only terrible, crushing humiliation, a dreadful, redfaced shame I hadn't felt since childhood" (p.601).

82 I take it that "being and nothingness", although not acknowledged as such, alludes to Sartre's L'être et le Néant.

83 In the Penguin translation (D. Magershack 1966) this confession is described on p.542.

84 This echoes the sentiments of the Chorus in Aeschylus, Choephoroi 400-402: "... drops of blood spilt on the ground demand more blood". Henry's purification ritual is modelled on classical usage, as described by Nilsson (1969:14-15): "The worst defilement that could be incurred was by shedding human blood. The pollution was washed off with watcr, like dirt. If a more thorough purification was needed, a sucking-pig was sacrificed and its blood used for cleansing ...." 
they were "okay" (p.423). But were they? The evidence, at least after the second murder, is negative.

In one of the most shocking passages in the novel, Richard describes Henry's behaviour at Bunny's funeral: "Slowly, slowly, with a drugged, fathomless calm, Henry bent and picked up a handful of dirt. He held it over the grave and let it trickle from his fingers. Then, with terrible composure, he stepped back and absently dragged the hand across his chest, smearing mud upon his lapel, his tie, the starched immaculate white of his shirt" (pp.496-497). Etymologically, "immaculate" conveys just the right nuance to highlight the enormity of Henry's action. This is nothing but ritual defilement, the besmirching of the suit symbolizing the uncleansed miasma of the soul. Thus, even Henry, the least scrupulous of the guilty foursome, betrays his remorse most vividly. Unlike Sartre's Roquentin, Camus' Meersault, or Freddy in John Banville's The Book of Evidence, Henry does have a conscience, although it is somewhat atrophied by disuse.

Of the Erinyes, Dodds (1951:42) remarks: "... it is only Euripides and Mr. T.S. Eliot who psychologise them as the pangs of conscience." 85 There may be no Furies in Tartt's novel, but in Book II the atmosphere of guilt and fear is so pervasive that it becomes almost as tangible as Aeschylus' Eumenides or Sartre's Flies. Three years after Bunny's death, Richard, Francis and Camilla still feel the need for cultic penance when they attend Mass in Boston (p.650). Their guilt would remain with them, however, as witness Richard's preoccupation with the theme of disguised evil in the Jacobean dramatists (pp.645-646).

Thus it transpires that, although no legal penalties are incurred, the culprits have to pay a heavy emotional price, as manifested by their inability to obtain ritual absolution from guilt. Plato's harsh penalties for privately practising orgiastic rites 86 appear almost mild in comparison.

\subsection{HAMARTIA}

It is against such a background that a second question should be considered: for what, exactly, are the students punished? In her elaborate treatment of this question, Tartt deviates sharply from her Euripidean model. Pentheus is punished, with physical sparagmos, for failing to acknowledge Dionysus' divine power. This is but the culmination of a series of prophecies87, warnings and threats uttered by Dionysus in the course of The Bacchae.88 Pentheus has ample opportunity to repent of being a theomachos (a rebel against the gods: cf. vv. 45,1255 ), but fails to avail himself of it. Consequently, Dionysus cannot but punish him.89 The sparagmos scene in The Secret History, however, does not

85 For a discussion of "conscience" in Euripides, cf. Bosman 1993:11-25. It is curious that Dodds fails to take cognizance of Sartre's Les Mouches, the publication of which antedated the first edition of Dodd's own magnum opus (1951) by eight years.

87 For the function of prologue prophecies in Euripides, see Hamilton 1978:277-302.

E.g. Bacchae 47-52, 516-517, 787-799, 837, 859-860.

In an instructive comparison of "divine punishment tragedies", Burnett (1970:15-29) demonstrates that Pentheus, unlike any other hero of punishment tragedy, "begins his play before he has committed a decisive offence" (p.19). For most of the play, therefore, punishment is "only a potential contingency" (p.18). This makes The Bacchae the one tragedy "that encompasses in its spectacle both the act of hybris and its consequent experience of nemesis" (p.19). 
constitute any punishment. The Vermont farmer is innocent of having slighted Dionysus; he is a mere pawn and no participant. This, in fact, is Fortune at her most outrageous: Aristotle would have taken Tartt to task for resorting to such a serendipitous provision of a victim. 90

Furthermore, Dionysus has no reason to punish the revelling students: they have proved themselves conscientious devotees of a cult of which the motto could be "nothing succeeds like excess". It could conceivably be argued that they are, conversely, punished with psychological sparagmos for having dabbled with Dionysus. But this would miss the point. First, punished by whom? Somehow, an omnipotent and just God doesn't fit into the novel's predominantly pagan framework. Further, although the second murder may be unleashed by Dionysian passion, it is planned and executed with Apollinian reason: thus Apollinian claritas triumphs over Dionysian confusio91. It is almost a case of oúdé $\pi \rho{ }^{\prime} \zeta$

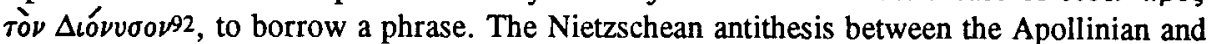
the Dionysian 93 , recently revived by Camille Paglia94 and popularized as the subtext of Oliver Stone's film The Doors ${ }^{95}$, is an important topos in The Secret History. Although the

90 Cf. Ars Poetica 1454b, where Euripides is criticized for his use of deus ex machina solutions in the Medea. A less negative verdict could, conceivably, be provided by the paradigm of Rene Girard, according to whom "the tragic action sacralizes violence by the choice of an arbitrary victim, a pharmakos or scapegoat, whose death or suffering removes violence from the realm of men and gives it back to the gods" (Segal 1986:52). If the operative word is arbitrary, Girard's approach does seem to be applicable to the position of the Vermont farmer. But there the resemblance ends: in Tartt's novel no "removal of violence" follows, as Bunny could testify from the dead.

91 The Latin terms are those of Young (1993:271).

92 Cf. Pickard-Cambridge 1966:74, 124-126, 295, where this phrase (literary: "nothing to do with Dionysus") refers to the introduction of non-Dionysian themes into performances in honour of Dionysus; Winkler \& Zeitlin, who use this phrase as title for a collection of stimulating articles, concluding that Athenian drama festivals, in fact, had "everything to do with Dionysus" (1990:3); Bierl 1991:4-13.

93 F.W. Nietzsche, Die Geburt der Tragödie, first published in 1872. Note that a quotation from Nietzsche also graces the page preceding the Prologue.

94 Sexual Personae. Art and Decadence from Nefertiti to Emily Dickinson (1990), especially Chapter 3. Aggressively self-assertive, refreshingly iconoclastic, Paglia equates Apollo with culture/maleness/the celestial and Dionysus with nature/femaleness/the chthonian: "The Dionysian is no picnic. It is the chthonian realities which Apollo evades, the blind grinding of subterranean forces, the long slow suck, the murk and the ooze. It is the dehumanizing brutality of biology and geology, the Darwinian waste and bloodshed, the squalor and rot we must block from consciousness to retain our Apollonian integrity as perșons" (pp.5-6).

Stylistically and thematically, Tartt would have found herself at home in this passage. By coincidence (?), Paglia taught at Tartt's alma mater, Bennington College in Vermont. But that was in 1972-1979; Tartt would not enrol till 1982. Nevertheless, the resemblance is uncanny.

In fact, Val Kilmer, in the persona of that most Dionysiac of rock poets, Jim Morrison, more than once acknowledges his creative impulse as "Dionysian"; this is in accord with a biography of Morrison (Hopkins \& Sugerman 1980: esp. 17-19, 34-35, 44-45, 98, 143, 156, 377). The name of the rock group is taken from Aldous Huxley's The Doors of Perception, which is also Dionysian in that it lauds the experience of mind-expanding narcotics. Huxley's title, in turn, derives from a poem by William Blake. Not surprisingly, Huxley himselt was inspired by Dionysus, as were Thomas Mann and Ezra Pound (Hall 1994:8). 
virtues of Apollo are never explicitly extolled, the god of reason lurks in the wings. Like Zeus in Prometheus Vinctus, he is present in his absence. Like Zeus, he imprints his authority via his agents. In Tartt's novel, the agent of reason - clinically cerebral, relentlessly rational - is Henry. Whereas the Dionysian experience is "essentially collective or congregational" (Dodds 1951:69), the Apollinian is individual and detached: Henry's decision to murder Bunny is virtually a one-man-show.

When Richard, after Bunny's death, attempts to identify the nature of their hamartia, his penchant for defensive rationalization precludes thorough soul-searching: "What we did was terrible, but still I don't think any of us were bad, exactly; chalk it up to weakness on my part, hubris on Henry's, too much Greek prose composition - whatever you like"96 (p.323). In retrospect, he mentions that his "fatal flaw" has always been "a morbid longing for the picturesque at all costs" (p.5).

Perhaps. But in view of Henry's powers of persuasion and manipulation, it is Henry's hubris, above all, that shapes the course of their vicissitudes. His hubris finds expression in intellectual arrogance, a trait shared to some extent by his friends. They regard themselves as socially superior to a Vermont jury (condescendingly labelled "telephoneoperators", p.205); the life of the farmer is perceived as worth less than that of Voltaire (p.230). In fact, they think they are above the law, and act accordingly. Nomoi are for hoi polloi; intellectuals may rely on their physis. Julian, of course, does nothing to detract from the hauteur of his protégés.

In the murkily grey area of morals, it is difficult to establish the exact aetiology of Henry's hamartia. Do he and his friends become amoral only as a pragmatic response to the pressures of chance circumstances, or are they inherently immoral - like Gide's eponymous protagonist - and evil? The major role of luck, chance and randomness in the novel would seem to substantiate the former possibility.

Soon after his arrival at Hampden, Richard recounts, "life itself seemed very magical ...: a web of symbol, coincidence, premonition, omen ...; some sly and benevolent Providence was revealing itself by degrees and I felt myself trembling on the verge of a fabulous discovery ..." (p.107). Such an optimistic belief in a "benevolent Providence" later proves to have been as naively ill-founded as the Chorus' fond hopes before Oedipus' discovery of his true pedigree97; Dr Johnson would have sardonically quipped that it represents "another triumph of hope over experience". Nevertheless, this passage betrays the valid perception that Fate does play a role in the novel, a perception which is later articulated with more realism: "It was just a horrible string of coincidences"98 (p.208).

96 The self-perception of criminals tends to be unrealistic, as witness the case of John Wayne Gacy, serial killer of 33 male persons up to 1978: "I'm an easy-going, fair-minded type: I treat people just like they treat me" (Sky News, 10/5/1994). The tendency in the U.S. to transfer guilt from the individual to society may be co-responsible for such shallow attempts at selfanalysis. To some extent Henry and his friends have, of course, had the misfortune to be fictionally exposed to this typically American malaise since birth.

97 Sophocles, Oedipus Tyrannus, vv.1086-1109.

98 The course of Tartt's novel is influenced by the following demonstrably fortuitous events: the statistically improbable intersection of the farmer's nocturnal route with that of the Bacchic revellers (p.198); Bunny happening to be asleep in Henry's flat when the revellers, conspicuously dishevelled, return from their bacchanal (p.208); Bunny (who "never reads the newspaper") "by some rotten stroke of luck" noticing the report of the manslaughter (p.215); Bunny's flash-in-the-pan deciphering of Henry's diary (p.223); Bunny's chance meeting with his friends above the ravine (p.317); Henry happening to find a newspaper photocopy 
On this evidence it could be argued that unlike Pentheus, who receives due warning, Tartt's protagonists are victims of the whims of Fate, and thus cannot be held fully accountable. Yet they do, like Oedipus 99 , have freedom of choice, even if partially constrained by events that are, or appear to be, outside their control. Neither Oedipus nor Henry is forced to persevere with making or thwarting discoveries, respectively. Henry's conscious, rational decision to murder Bunny is nothing less than evil, whereas his accomplices' inability to distance themselves from his immoral world betrays their amorality, manifested in moral turpitude and laissez faire inertia.

Part of the reason for apportioning full blame and responsibility to Henry, is his slickly self-assured attitude toward the unexpected and the fateful. The unpredictability of chance does not constitute a threat to him; in fact, as a gambler, he thrives on uncertainty and the challenge of imponderables. Like a true Roman, he even believes in divination (p.72) and omens (p.404). Whereas Francis regards "design" as preferable to "chance" in their plans to murder Bunny, Henry prefers "luck", i.e. "allowing Bunny to choose the circumstances of his own death" (p.301). Not surprisingly, Henry regards the murder plans as "a chess problem. A game" (p.295). With regard to poker, he concedes that "there's a certain random element in it which appeals to me" (p.232). True to his aleatory temperament, it is while playing poker that he conceives the idea of Bunny's demise. In retrospect, even Richard, predictably defensive, argues that their murder plans appeared like a game to him (p.325). Henry's penchant for playing fatal games (ludi) with Fate invites deconstruction: the classical clique's collusion to pelude detection leads to disillusionment. In this paradigm, a deluded Henry is ultimately beaten at his own game; the joke is on a protagonist for whom the agon has proved to be agony. Instead of winning a prize, he pays a price. 100

Although, to Tartt's credit, Henry's character is not so one-sided as to evoke no sympathy, there is something sinister about him. His austere dress and the lack of emotion behind his well-mannered facade101 lend him a somewhat macabre aura, exacerbated by a propensity for violence (pp.53, 223, 250) and cynical manipulation. The Greeks may have had no Devil (p.85), but on occasion Henry is portrayed with more than a hint of the demonic.

concerning the manslaughter on Bunny's desk and burn it before the police could discover this potentially incriminating evidence (p.366); Bunny's letter of accusation being put "by mistake" into the box of $\mathrm{Mr}$ Morse, who happens to be on sabbatical (p.587); the normally scatterbrained Julian for once not being thwarted by his enterprising students from authenticating Bunny's letter (pp.592-601).

99 I am following the now orthodox interpretation of Bernard Knox (e.g. in his introduction to Fagles' Penguin translation of Sophocles, The Three Theban plays, 1982, especially pp.134$135,145-150)$. In a recent article, Peradotto (1992:1-15), however, advocates a "sophistic" reading of the Oedipus Tyrannus, highlighting events that appear to be either random or caused by Apollo: "Why ... does [Aristotle] make Oedipus Tyrannus the paradigm of tragic composition, a play so riddled with chance, so crippled by coincidence, as to be ruled out of consideration by the scientist's touchstones of probability and necessity?" (1992:4).

100 For comparable etymological gamesmanship, see Huizinga 1949:30, 49-50, 55-56, 64-65; Koestler 1969:50.

101 This discrepancy between appearance and reality is naively misinterpreted by Mr Corcoran: "Never judge a book by its cover. Old Henry here may look like he's got a stick up his butt but there never breathed a finer fella" (p.463). 
Though he lacks Saladin Chamcha's hirsute appearance102, it comes as no surprise when he is compared to Satan (p.112). Mrs Corcoran's innocuous cliché "speak of the Devil" acquires a sinister significance when applied to Henry, who is described as "in dark suit" and "with a stiff, measured tread" (p.462). His diabolical scheming is curiously at odds with his puritanically prim vocabulary. The quaintly anachronistic expression "Goodness"103, favoured by him and, more plausibly, by Julian104, belies his own moral malaise and begs to be deconstructed. To cap it all, he even has the chutzpah to berate Charles for swearing (p.616).

\subsection{MORAL SIGNIFICANCE}

Such inconsistency between words and actions reflects the quintessentially Greek dichotomy between logoi and erga, an antithesis that finds expression, inter alia, in Socrates' erroneous assumption that (intellectual) knowledge guarantees (practical) morality, that moral error is somehow merely "a ... mistake in perspective" (Dodds 1951:212) that can be corrected with a "scientific moral arithmetic" (Dodds 1951:185). Instead of succumbing to this intellectualist fallacy, Henry would have been better served

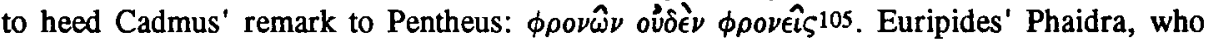
experienced human fallibility the hard way, also realized the limitations of knowledge as a key to virtue106, as did Ovid107 and the apostle Paul108.

Hampden's motto, ironically, is "Learn by doing" (p.446). In the harsh world of The Secret History, this is akin to the Aeschylean $\pi \alpha \theta^{\prime} \theta \epsilon \mu_{\alpha}^{\prime} \theta_{0}$ ○: the lessons that Richard and his friends learn, are indeed painful. It is tragic that when they have acquired this knowledge, it is too late to rectify their mistakes.

The ambiguously empty ending of the novel confirms that Tartt offers no easy solution not even a desperate sleight of hand like Camus, who manages to imagine the eternally

102 In The Satanic Verses Saladin Chamcha, after literally falling from heaven, is temporarily metamorphosed into a devil; his counterfoil, Gibreel Farishta, becomes an (arch)angel, as his name indicates.

103 E.g. pp.199, 216, 220, 226, 250, 352, 411. Also cf. Richard's "Geez" (p.88) and "Golly" (p.89), and Julian's "Dear me" (p.411).

104 Julian appears to be innocuously goody-goody, but Henry's description of him as "a divinity" (p.372) does not do justice to his tutor's irresponsibility. Having sown the seeds of the Dionysiac (pp.44-47), Julian fails to intervene when his students' behaviour gets out of hand, even though he is aware of the farmer's death (p.283) and has his suspicions about Bunny's fate (p.354).

"In spite of your cleverness, you lack wisdom." (Bacchae 332; also cf. 656-657).


understand what is right and realize it, but we fail to carry it out" (Barrett 1978:227)). See further Claus 1972:223-238 and Moline 1975:45-67.

107 Video meliora proboque, deteriora sequor ("I am aware of better options, but I adhere to the worst").

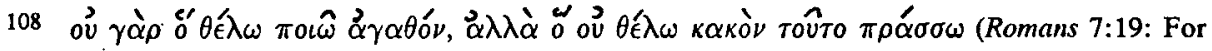
the good that I desire, I fail to do; but the evil that I don't desire, ... that I do). 
toiling Sisyphus as happy ${ }^{109}$, or the film version of Kundera's The unbearable lightness of being, where the fatal accident of Tomas and his friends is imbued with a kind of existentialist bliss. The fate of Tartt's central characters makes it clear that her novel reflects the anthropological tenets of Hobbes (homo homini lupus) rather than those of Rousseau. Like the bloodthirsty boys in Lord of the Flies, Henry and his friends do become savages, at least for the duration of their bacchanal, but that hardly makes them either noble or innocent, as Rousseau would have it. Instead, they become Hobbesian predators, intent on self-preservation. In fact, their all too human actions and reactions could be explained in terms of the very same motives the Athenian ambassadors, on the eve of the Peloponnesian War, use to justify Athenian imperialism: fear, prestige and selfinterest110. Paradoxically, the revellers' aim was "to lose themselves" (p.192). Ultimately, they manage to achieve just that - but in a less glorious and more lasting way than envisaged.

\section{CONCLUSION}

"How many ages hence/ Shall this our lofty scene be acted over/ In states unborn and accents yet unknown!"111 Thus Shakespeare's Cassius after the assassination of Julius Caesar. This prophecy also holds true for the nachleben of Euripides' Bacchae, which would both perplex and enrich literary critics, psychologists and anthropologists in ages to come, and still provides material for new versions. The most recent noteworthy dramatic adaptations of The Bacchae even include African112 and Japanese113 tragedies.

Tartt's adaptation of Euripides' drama is exceptional in that the sparagmos scene in which Pentheus' hubris culminates, provides an intertextual basis for no more than a shortish subplot in a lengthy novel. This scene does, however, prove pivotal, unleashing a chain of events that would have seemed implausible in the absence of any need for the initial sparagmos to be covered up. It should be emphasized that these events do not per se necessitate a classical field of reference. Nevertheless, Tartt's cast of characters ensures that the Classics receive due reference throughout the novel without such allusions appearing contrived.

At face value, the popularity of The Secret History could be ascribed to obvious structural considerations such as a slick plot ingeniously paced to achieve suspense. But perhaps the impact of Tartt's novel is also due to philosophical considerations: it holds a mirror to the nihilism of our time114 by employing an antithesis that has not lost any of its topicality,

109 "Il faut imaginer Sisyphe heureux" (Le mythe de Sisyphe, Gallimard 1942:166).



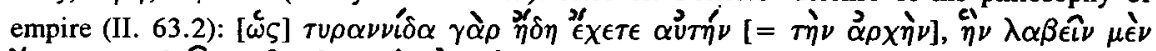

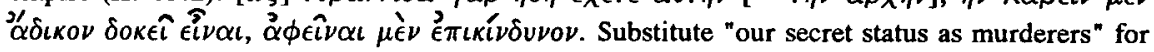
"empire", and this passage becomes uncannily applicable to Tartt's protagonists.

111 William Shakespeare, Julius Caesar III.i. 111-113.

112 Wole Soyinka 1973. The Bacchae of Euripides, discussed by Conradie (1990:61-74).

113 Suzuki Tadashi's Bacchae, reviewed by Mackinnon (1992:489-490).

114 Cf. De Jong 1994:7-8, who compares it to the fin de siècle pessimism and decadence of a century ago. 
viz. that of the Apollinian vs. the Dionysian115. This contrast can still most vividly be highlighted within a classical framework. The fate of Tartt's characters demonstrates that neither allegiance to Dionysian physis nor to Apollinian nomos can by itself provide a solution for the malaise of our time. True to the nihilistic atmosphere that pervades the novel, the author refrains from suggesting any remedy: she describes rather than prescribes.

Tartt has done the beleaguered Classics a service by demonstrating that the elite world of six Classics students can be made thrillingly accessible to the lay person. Some readers may experience the nostalgic desire evoked by Wordsworth's sonnet: "I'd rather be / A Pagan suckled in a creed outworn;/ So might I, standing on this pleasant lea,/ Have glimpses that would make me less forlorn;/ Have sight of Proteus rising from the sea;/ Or hear old Triton blow his wreathed horn" 116 .

Tartt's novel does, however, raise a question that should cause concern: do the Classics tend to breed conceit? Henry's intellectual hubris certainly seems to justify such a deduction. It is up to classicists, here and abroad, to prove him the exception rather than the rule. In view of the traditionally elitist stance of the Classics, this challenge is a daunting one. But at a time when tertiary education in South Africa is becoming more populist, the onus is on classicists to demonstrate that, unlike Henry, they are not out of touch with the needs of hoi polloi and that the Classics can indeed cater for such needs.117 That the Classics can be popularized has, after all, been demonstrated most convincingly by Donna Tartt in The Secret History.

\section{BIBLIOGRAPHY}

Barrett, W.S. (ed.) 1978. Euripides: Hippolytos. Oxford: Oxford University Press.

Bierl, A.F.H. 1991. Dionysos und die griechische Tragödie. Classica Monacensia, Band 1. Tübingen: Gunter Narr Verlag.

Bosman, P.R. 1993. "Pathology of a guilty conscience: the legacy of Orestes." Acta Classica 36:11-25.

Burnett, A.P. 1970. "Pentheus and Dionysus: host and guest." Classical Philology 65:15-29.

Capra, F. 1983. The Tao of Physics. An exploration of the parallels between modern physics and Eastern mysticism. London: Flamingo/Fontana.

Cartledge, P. 1993. The Greeks. A portrait of self and others. Oxford: Oxford University Press.

115 Dionysus continues to provide material for new interpretations. Hall 1994:8 ascribes this to his "protean" nature, and notes that he has been variously interpreted as "a proto-Christ, a god of marginal and protest groups, a figurehead in the 1960s for advocates of free love, and a symbol for gay liberationists". See further Winkler \& Zeitlin 1990 and Bierl 1991.

116 Tartt herself, significantly, does not regard a "Pagan ... creed" as "outworn", as she admits in an interview: "I think we have much more in common now with the ancient Greeks than with, say, a medieval Christian. ... We really do live in an age of new paganism" (Hunnewell 1992:3).

117 For a positive stance on this issue, see Dominik 1992. For further positive suggestions, see Claassen 1990, Conradie 1989 and 1990, and Lambert \& Masoga 1994. 
Cilliers, L. 1986. Die Bakchante van Euripides. Acta Academica Reeks C no.10. Bloemfontein: U.O.V.S.

Claassen, J.M. 1990. Editorial. Akroterion 35:1.

Claus, D. 1972. "Phaedra and the Socratic paradox." Yale Classical Studies 22:223-238.

Cohen, D. 1991. Law, society and sexuality. The enforcement of morals in classical Athens. Cambridge: Cambridge University Press.

Cohen, D. 1992. "Sex, gender and sexuality in ancient Greece." Classical Philology 87:145-160.

Conradie, P.J. 1989. Editorial. Akroterion 34:159.

Conradie, P.J. 1990. Editorial. Akroterion 35:89.

Conradie, P.J. 1990. "Syncretism in Wole Soyinka's play The Bacchae of Euripides." South African Theatre Journal 4:61-74.

De Jong, T. 1994. "Alles komt terug. De rol van de geschiedenis in The Secret History." Hollands Maandblad 1994(3):6-13.

Dodds, E.R. 1951. The Greeks and the irrational. Los Angeles: University of California Press.

Dodds, E.R. (ed.) 1960. Euripides' Bacchae. Oxford: Oxford University Press.

Dominik, W.J. 1992. "Quo Vadimus? Classics at the Crossroads." Theoria 80:164-170.

Dostoyevsky, F. 1966. Crime "and Punishment (trans. by D. Magershack). Harmondsworth: Penguin.

Foley, H.P. 1980. "The masque of Dionysus." Transactions of the American Philological Association 110:107-133.

Gardner, J. 1989. "Aristophanes and male anxiety - the defence of the oikos." Greece \& Rome 36:51-62.

Gould, J. 1980. "Law, custom and myth: aspects of the social position of women in classical Athens." Journal of Hellenic Studies 100:38-59.

Green, P. 1989. "Delphic responses", in: Classical Bearings. Interpreting ancient history and culture (Ch. 6, pp.91-111). London: Thames \& Hudson.

Halperin, D.M. 1990. "Why is Diotima a woman? Platonic Eros and the figuration of gender", in: Before sexuality: the construction of erotic experience in the ancient Greek world, ed. Halperin, D.M. et al. (pp.257-308). Princeton: Princeton University Press.

Hall, E. 1994. "Dionysiac Revels": Review of Carpenter, T.H. \& Faraone, C.A. (eds.). Masks of Dionysus. Times Literary Supplement, April 15:8.

Heijne, B. 1994. "De motieven van een seriemoordenaar." Cultureel Supplement N.R.C. Handelsblad, 9 September. 
Henrichs, A. 1990. "Between country and city: cultic dimensions of Dionysus in Athens and Attica", in: Cabinet of the Muses. Essays on classical and comparative literature in honor of Thomas G. Rosenmeyer, ed. M. Griffith and D.J. Mastronardo (pp.257-277). Atlanta: Scholars Press.

Hopkins, J. \& Sugerman, D. 1980. No one here gets out alive. New York: Warner Books.

Huizinga, J. 1949. Homo Ludens. A Study of the Play Element in Culture. London: Paladin.

Hunnewell, S. 1992. "Her duty is to fool the reader." The New York Times Book Review, September 13:3.

Knox, B. (introd.) 1982. Sophocles: The Three Theban Plays. Harmondsworth: Penguin.

Koestler, A. 1969. The act of creation. London: Pan/Picador.

Lambert, M. \& Masoga, M.L. 1994. "A Pan-African Response to the Classics." Akroterion 39:75-82.

Lambert, M. \& Szesnat, H. 1994. "Greek 'homosexuality': whither the debate?" Akroterion 39:46-63.

MacKinnon, K. 1992. Review of McDonald, M. 1992. Ancient Sun, Modern Light: Greek Drama on the Modern Stage. Classical Review (NS) 42:489-490.

Maxwell-Stuart, P.G. 1971. "Dionysus and the fawnskin." Classical Quarterly 21:437439.

Moline, J. 1975. "Euripides, Socrates and virtue." Hermes 103:45-67.

Nietzsche, F.W. 1967. The birth of Tragedy and the case of Wagner. New York: Vintage Books.

Nilsson, M.P. 1969. Greek Piety. New York: The Norton Library.

Paglia, C. 1990. Sexual Personae. Art and Decadence from Nefertiti to Emily Dickinson. New York: Vail Ballou Press.

Parke, H.W. 1967. Greek Oracles. London: Hutchinson.

Pauw, F.R. 1994. "'If on a winter's night a reveller': the classical intertext in Donna Tartt's The Secret History, Part 1." Akroterion 39:141-163.

Peradotto, J. 1992. "Disauthorizing Prophecy: The ideological Mapping of Oedipus Tyrannus." Transactions of the American Philological Association 122:1-15.

Pickard-Cambridge, A. 1966. Dithyramb, Tragedy and Comedy: Oxford: Oxford University Press.

Seaford, R. 1981. "Dionysiac drama and the Dionysiac mysteries." Classical Quarterly 31:252-275.

Segal, C. 1977. "Euripides' Bacchae: Conflict and Mediation." Ramus 6:103-120.

Segal, C. 1982. Dionysiac Poetics and Euripides' Bacchae. Princeton: Princeton University Press. 
Segal, C. 1986. "Greek tragedy and society: a structuralist perspective", in: Greek tragedy and political theory, ed. J.P. Euben (pp.43-75). Los Angeles: University of California Press.

Tartt, D. 1993. The Secret History. Harmondsworth: Penguin Books.

Venables, S. 1989. Everest: Kangshung Face. London: Hodder \& Stoughton.

Winkler, J.J. 1990. "Laying down the law: the oversight of men's sexual behavior in classical Athens", in: Before sexuality: the construction of erotic experience in the ancient Greek world, ed. Halperin, D.M., Winkler, J.J. \& Zeitlin, F.I. (pp.171210). Princeton: Princeton University Press.

Winkler, I.J. \& Zeitlin, F.I. 1990. "Introduction", in: Nothing to do with Dionysos? Athenian drama in its social context, ed. Winkler \& Zeitlin (pp.3-11). Princeton: Princeton University Press.

Young, D. 1993. Origins of the Sacred. The ecstasies of love and war. London: Abacus.

Zukav, G. 1979. The dancing Wu Li masters. An overview of the New Physics. Bungay, Suffolk: Flamingo/Fontana. 